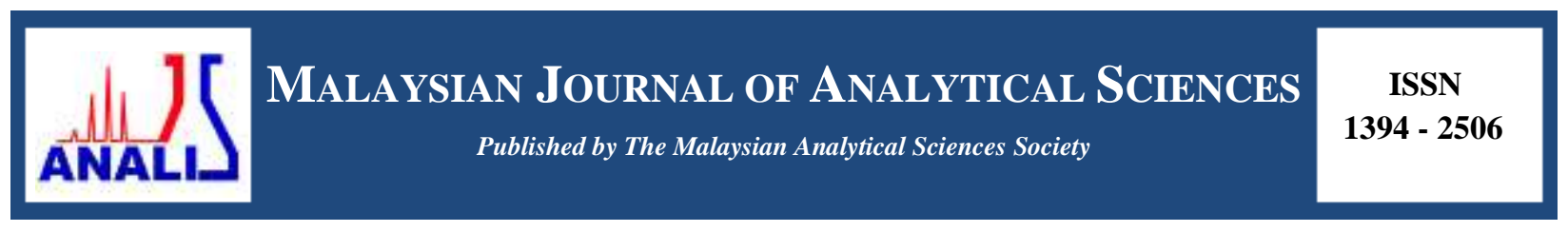

\title{
IRON(II) COMPLEX OF ANTHRAQUINONE: SYNTHESIS, STRUCTURAL ELUCIDATION AND ANTIMICROBIAL ACTIVITY
}

\author{
(Komplek Ferum(II) Antrakuinon: Sintesis, Penentuan Struktur Organik dan Aktiviti \\ Antimikrob) \\ Nur Dzaina Zaidel, Vivien Jong Yi Mian*, Mohammad Isa Mohamadin \\ Faculty of Applied Sciences \\ Universiti Teknologi MARA, 94300 Kota Samarahan, Sarawak, Malaysia \\ *Corresponding author: vivien@sarawak.uitm.edu.my
}

Received: 21 August 2016; Accepted: 27 July 2017

\begin{abstract}
Our continuing interest in anthraquinone had led the researchers to look at the synthesis of metal complex by reacting our major compound, nordamnacanthal with transition metal, Fe(II). Fe(II)-nordamnacanthal complex had been synthesized successfully via telescoping synthesis/ one-pot reaction. The ligand and its metal complex were established by 1D and 2D nuclear magnetic resonance spectroscopy, UV-Visible, CHNS analyzer, gas chromatography mass spectrometry and infrared analysis. They were evaluated for their antimicrobial activity using minimum inhibitory concentration (MIC) and minimum bactericidal concentration (MBC). Fe(II)-nordamnacanthal complex showed stronger inhibition against Pseudomonas aeruginosa at the concentration of $450 \mu \mathrm{g} / \mathrm{mL}$ while Proteus vulgaris, Klebsiella pneumoniae and Salmonella pneumoniae at the concentration of $225 \mu \mathrm{g} / \mathrm{mL}$ compare to nordamnacanthal. In this work, the synthesized compound, Fe(II)-nordamnacanthal showed better antimicrobial activity compared to the ligand itself.
\end{abstract}

Keywords: nordamnacanthal, transition metal Fe(II), Fe(II)-nordamnacanthal complex, antimicrobial activity

\begin{abstract}
Abstrak
Kesinambungan perhatian kami terhadap antrakuinon telah membawa kami untuk melihat kepada sintesis kompleks logam dengan menghasilkan tindak balas sebatian utama kami, nordamnacanthal dengan logam peralihan, Fe(II). Kompleks Fe(II)nordamnacanthal telah berjaya disintesiskan melalui teleskop sintesis/tindak balas satu-periuk. Sebatian dan kompleks logam dikenalpasti melalui 1D dan 2D spektroskopi resonan magnetik nukleus, UV-Vis, CHNS, kromatografi gas spektometri jisim dan analisis inframerah. Sebatian dan kompleks logam tersebut telah dinilai untuk aktiviti antimikrob dengan menggunakan kepekatan perencatan minimum (MIC) dan minimum kepekatan bakteria (MBC). Kompleks Fe(II)-nordamnacanthal menunjukkan perencatan yang kuat terhadap Pseudomonas aeruginosa pada kepekatan $450 \mu \mathrm{g} / \mathrm{mL}$ manakala Proteus vulgaris, Klebsiella pneumoniae dan Salmonella pneumoniae pada kepekatan $225 \mu \mathrm{g} / \mathrm{mL}$ berbanding dengan nordamnacanthal. Dalam kajian ini, sebatian yang disintesis, kompleks Fe(II)-nordamnacanthal menunjukkan aktiviti antimikrob lebih baik berbanding dengan sebatian itu sendiri.
\end{abstract}

Kata kunci: nordamnacanthal, logam peralihan Fe(II), kompleks Fe(II)-nordamnacanthal, aktiviti antimikrob

\section{Introduction}

Anthraquinones are biocompounds that are widely obtained from fungi and higher plant families [1, 2]. Anthraquinones have nearly one thousand known compounds, which contain different types of substituents at different positions, leading to a large variety of pharmacological activities [3, 4]. The bioactivities of these 


\section{Nur Dzaina et al: IRON(II) COMPLEX OF ANTHRAQUINONE: SYNTHESIS, STRUCTURAL ELUCIDATION AND ANTIMICROBIAL ACTIVITY}

compounds can be attributed to their structure. Presence of substituents namely $\mathrm{OH}$ group and carbonyl group on the ring structure of anthraquinones opens up a possibility of forming a coordinated bond with metal ions. The inclusion of transition metal ion is expected to increase the planarity of the compound thus will enhanced the bioactive properties of the new prepared complexes. Anthraquinones structures also plays an important role in the cancer activity as it allows for many sites for the phenolic group substituents on the bridged benzene rings on either side of the carbonyl bridge, while still maintaining its aromaticity. This allows for intercalation of the anthraquinones to DNA in cells, as well as hydrogen bonding between the carbonyl and ether bridges with amino acid residues in enzymes [5].

Similarly, the anthraquinones' structure also plays an important role in the cancer activity of Morinda citrifolia as it allows for many sites for the phenolic group substituents on the bridged benzene rings on either side of the carbonyl bridge, while still maintaining its aromaticity. This allows for intercalation of the anthraquinones to DNA in cells, as well as hydrogen bonding between the carbonyl and ether bridges with amino acid residues in enzymes [2].

The underlying bioactive role of such compounds relates to the intracellular interaction of the compounds with DNA molecule with one of the effects is leading to the damaged of the cell. Such disruptive consequence is an inhibitor to the continuous growth of cell and thus resulting in cell death [6]. The inclusion of transition metal complexes namely copper, zinc and iron could enhance such bioactive role of the compounds. This is particular as the presence of such metals could alter the overall structure of the newly formed complex and thus can increase the affinity of the compound to DNA [7, 8].

This could result in the improvement of biological activities of the compounds. This research was carried out on Morinda citrifolia and focused on isolation of anthraquinones from the Morinda citrifolia stem bark extract and synthesize of $\mathrm{Fe}(\mathrm{II})$ complex which is having anthraquinones as ligands.

\section{Plant material}

\section{Materials and Methods}

An amount $5-6 \mathrm{~kg}$ of stem barks sample of Morinda citrifolia were collected from Sarawak. Herbarium voucher specimens were prepared.

\section{Extraction, isolation and purification}

The plant was allowed to air-dry in the laboratory and then the dried sample was grinded. Powdered air-dried samples $(2-3 \mathrm{~kg})$ were extracted by soaking the sample with organic solvents in sequential polarity which started with hexane and followed by ethyl acetate, chloroform and methanol. The samples were allowed to stand for 48 hours and the process was repeated twice at 48 hours-interval.

The extract from each solvent extraction was filtered and concentrated using a rotavapor under vacuum pressure. The extracts were purified using liquid vacuum column (KCV) chromatography, gravity column chromatography and chromatoron. Fractions which were obtained from the isolation were purified using the gravity column chromatography and chromatotron using hexane and chloroform with ratio (6:4) as a solvent system to obtain the major compound, nordamnacanthal.

\section{Preparation of the metal complex}

$\mathrm{Fe}(\mathrm{II})$-nordamnacanthal complex was synthesized by reacting the major compound, nordamnacanthal, $0.0500 \mathrm{~g}$, $0.1864 \mathrm{mmol}$ with an ethanolic solution $30 \mathrm{~mL}$ of $0.0186 \mathrm{~g}, 0.0932 \mathrm{mmol}$ iron(II) acetate. The mixture was stirred and refluxed for 3 hours. Brown precipitate was yielded during the reflux. It was allowed to cool at the room temperature and was filtered. The solid was washed with ethanol and then air-dried.

\section{Instrumentation}

The ligand, nordamnacanthal and its metal complex were established by gas chromatography mass spectrometry (GCMS), nuclear magnetic resonance (NMR), UV-Visible spectra, Fourier transformation infrared spectrophotometer and CHNS elemental analyzer. 


\section{Bioassay (antimicrobial)}

Antimicrobial nordamnacanthal and Fe(II)-nordamnacanthal were evaluated using minimum inhibitory concentration (MIC) determines by broth micro dilution method using 96-well microplates against the 5 bacteria, Escherichia coli, Salmonella pneumoniae, Pseudomonas aeruginosa, Proteus vulgaris and Klebsiella pneumonia. The MIC will be tested according to Güllüce et al. [9]. Nutrient broth was prepared and autoclaved. $3.6 \mathrm{mg}$ of ligand and its metal complex were weighed and dissolved in $2 \mathrm{~mL}$ DMSO (Stock solution, $1800 \mu \mathrm{g} / \mathrm{mL}$ ).

The inoculated of the microbial strains were prepared from 24 hours broth cultures and suspensions were adjusted to $0.5 \mathrm{McF}$ arland standard turbidity. The sterile nutrient broth was added $(100 \mu \mathrm{g} / \mathrm{mL})$ to wells in row B to $\mathrm{H}$. The stock solution was added $(100 \mu \mathrm{g} / \mathrm{mL})$ to row A and B. The well mixture of nutrient broth and sample at row B were transferred to each well in order to obtain a twofold serial dilution of stock samples $(1800,900,450,225$, $112.5,56.25,28.13$ and $14.07 \mu \mathrm{g} / \mathrm{mL}) .100 \mu \mathrm{g} / \mathrm{mL}$ of the last row of the well need was removed out. The prepared bacteria were added $(100 \mu \mathrm{g} / \mathrm{mL}$ ) to all wells (A to H). T96-wells plate were covered with lid, sealed and incubated at $37^{\circ} \mathrm{C}$ for 24 hours. The microbial growth was observed by turbidity and present of pallet at the bottom.

Minimum bactericidal concentration (MBC) method was used to extend evaluating the results of MIC by determine the number of surviving organism by observing the growth of bacteria. MBC is defining as the number concentration at which $99 \%$ of the bacteria were killed. The solution at the clearest stage/concentration in the 96wells plate (during MIC analysis) were taken out and spread on the plate containing agar using sterilized metal loop. The plates were sealed and incubated at $37{ }^{\circ} \mathrm{C}$ for 24 hours. The plates were observed. The plate was clear during observation, means the bacteria are not growth and the MBC result is the same as MIC. Meanwhile, if the agar turns cloudy or not clear, MBC result showed concentration one step lower than MIC.

\section{Structural elucidation of nordamnacanthal}

\section{Results and Discussion}

Nordamnacanthal was isolated via column chromatography $(\mathrm{CC})$ and recrystallised from chloroform as an orangeyellow solid and with the melting point of $217-218{ }^{\circ} \mathrm{C}$ Temperature of this compound ranging $218-220{ }^{\circ} \mathrm{C}$ was reported by Prista et al. [10]. The phenolic nature of this compound was indicated by the positive $\mathrm{FeCl}_{3}$ test. The difference can be noticed from the molecular ion peak at $\mathrm{m} / \mathrm{z} 268$, which corresponds to the molecular formula $\mathrm{C}_{15} \mathrm{H}_{8} \mathrm{O}_{5}$. Strong peak at $\mathrm{m} / \mathrm{z} 240$ was due to the $\alpha$-cleavage of the bond to the carbonyl group also occurred in nordamancanthal. The difference of the two compounds can also be observed from the UV spectrum where the absorption wavelength of nordamnacanthal was centered at $246 \mathrm{~nm}$ while another was shifted longer wavelength at $290 \mathrm{~nm}$. This is due to the pi-pi* transition in the aromatic rings. There was also an additional weak absorption at $420 \mathrm{~nm}$ that indicating the hydroxyl group. The IR spectrum showed strong absorption bands at $v=3071,1667$, $1573,1456,1309$ and $1262 \mathrm{~cm}^{-1}$ were due to the presence of the hydroxyl group, chelated carbonyl group and the C-O stretch, respectively.

The ${ }^{1} \mathrm{H}$ NMR spectrum showed a singlet signal of aromatic proton $\left(\delta_{\mathrm{H}} 7.34, \mathrm{H}-4\right)$ and two doublet of doublets protons $\left(\delta_{\mathrm{H}} 8.32, \mathrm{H}-5\right.$ and $\left.\mathrm{H}-8\right)$ and two multiplets at $\delta_{\mathrm{H}} 7.84$ (H-6 and $\left.\mathrm{H}-7\right)$. The five signals at aromatic range displayed signals for a 1,2,3-trisubstituted aromatic ring. The assignments were made according to the equivalent protons values of the two protons and their coupling constant values which were 7.3 and $1.8 \mathrm{~Hz}$. These values also confirmed the occurrence of the orto coupling and meta coupling among these protons. The characteristic ${ }^{13} \mathrm{C}$ NMR spectra revealed a normal skeleton of anthraquinone attached by two hydroxyl, and a formyl group.

Additional information from the HMBC proved the assignment of the formyl group in the structure, the ${ }^{3} \mathrm{~J}$ coupling between the aldehyde proton at $\delta_{\mathrm{H}} 10.50$ and C-3 $\left(\delta_{\mathrm{C}} 169.2\right)$, and $\delta_{\mathrm{C}} 168.1(\mathrm{C}-1)$ with the one proton singlet at $\delta_{\mathrm{H}}$ 7.34 was assigned as $\mathrm{H}-4$. Besides, the substituents in the ring A were identified to have the two hydroxyl groups at position 1 and 3, and the formyl group at position 2. The positions of these substituents were confirmed by the two one-proton singlets at $\delta_{\mathrm{H}} 14.06$ and 12.68 , that represented the chelated hydroxyl protons.

\section{Characterization of Metal Complex}

The structure of Fe(II)-nordamnacanthal complex was established through the elemental analysis CHNS, IR and UV-Visible spectral data. The synthesis of metal complex was carried out by reacting our major compound, 
nordamnacanthal with transition metal, Fe(II). Fe(II)-nordamnacanthal complex had been synthesized successfully via telescoping synthesis/ one-pot reaction. The ligand, nordamnacanthal (L) on interaction with iron(II) acetate. The analytical data show that the metal to ligand ratio is 1:2. (yield $42 \%$ ). Elemental analysis was found to be $\mathrm{C}$ (39.97\%); H (3.514\%); N (0.2777\%) and S (0.06\%). Calculated for Fe(II)-nordamnacanthal complex: C (40.00\%); $\mathrm{H}(3.111 \%) ; \mathrm{N}(0.0 \%)$ and $\mathrm{S}(0.0 \%)$. The Fe(II)-nordamnacanthal complex showed molecular ion peak at $\mathrm{m} / \mathrm{z} 450$, supported the formation of the complex.

IR spectra of the free ligand, nordamnacanthal (Figure 1) was compared with the IR spectra of the metal complex. IR spectra of ligand showed a strong band at $3071 \mathrm{~cm}^{-1}$ that is assigned to the $\mathrm{OH}$ group while the band is gone in the spectra of $\mathrm{Fe}$ (II) complex indicating the coordination of the hydroxyl group through the deprotonation. Broad absorption band at $3429 \mathrm{~cm}^{-1}$ in the spectra of $\mathrm{Fe}$ (II) complex may show the presence of $\mathrm{H}_{2} \mathrm{O}$ stretching vibration. The band position of $v(\mathrm{C}=\mathrm{O})$ group appeared at $1658-1667 \mathrm{~cm}^{-1}$ range in the spectra of the free ligand was shifted by in the spectra of the complex, indicating the coordination of $\mathrm{C}=\mathrm{O}$ of the ring to the $\mathrm{Fe}$ ion. While the additional peaks a very low frequency in IR spectra of Fe(II)-nordamnacanthal complex at $463.05 \mathrm{~cm}^{-1}$ was attributed to $v$ (MO), which was supported the formation of the complex [11].

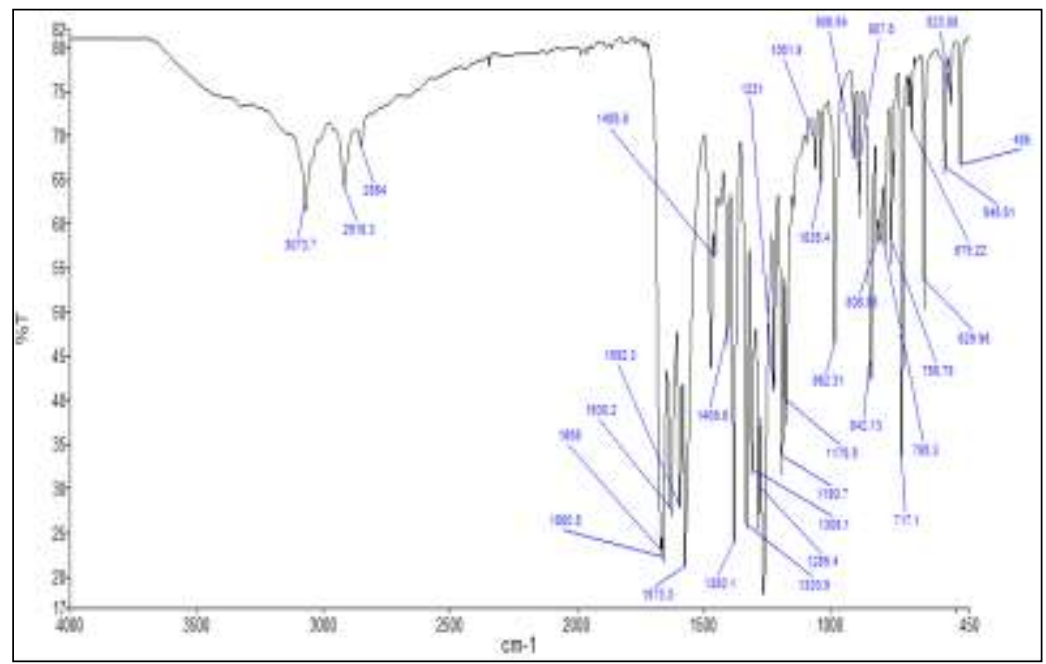

Figure 1. FTIR spectrum of nordamnacanthal

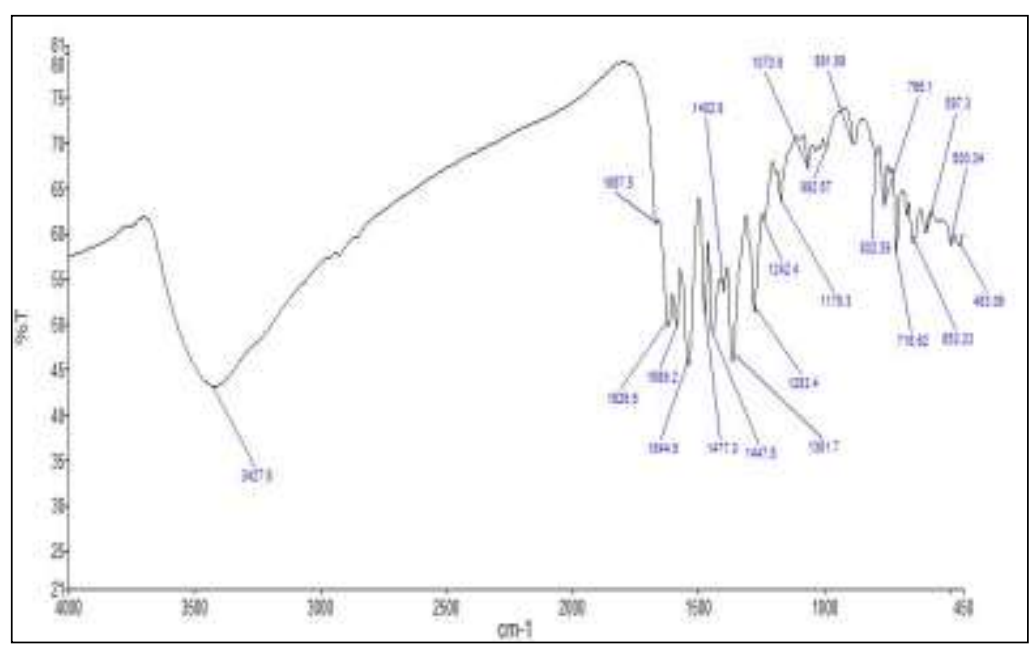

Figure 2. FTIR spectrum of Fe(II)-nordamnacanthal complex 
The UV-Vis absorption spectra of nordamnacanthal (Figure 3) showed bands at 258.21 and $268.71 \mathrm{~nm}$, which are due to $\pi \rightarrow \pi^{*}$ intra ligand transitions. The absorption band were shifted from 258.21 to 274.70 and 268.13 to 309.89 respectively in UV-vis spectra of Fe (II)-nordamnacanthal complex (Figure 4) and additional absorption at 421.78 was shifted to $548.05 \mathrm{~nm}$ in Fe (II)-nordamnacanthal complex may be due to a metal-to-ligand charge transfer [12]. Based on these results, ligand nordamnacanthal was confirmed coordinate with Fe(II) metal.

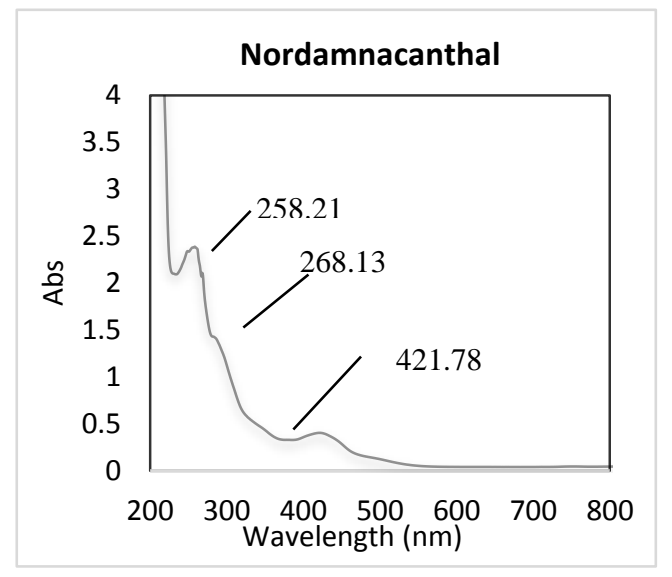

Figure 3. UV VIS spectra of nordamnacanthal

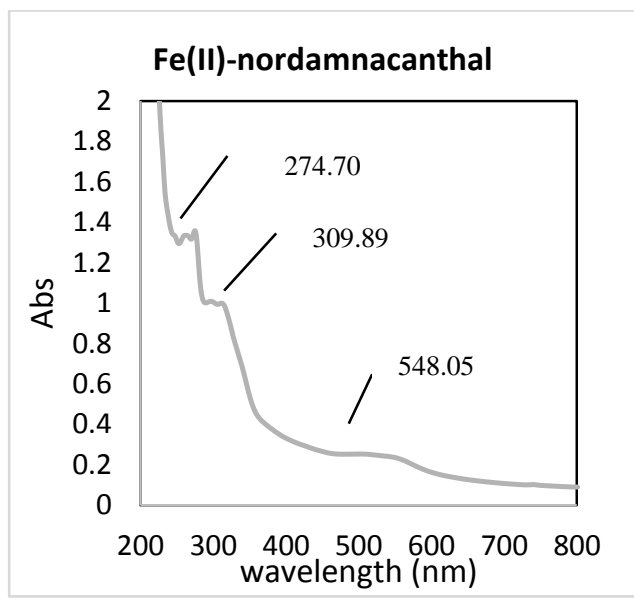

Figure 4. UV VIS Spectra of Fe(II)-nordamnacanthal complex

\section{Antimicrobial activity}

Antimicrobial activity of the ligand, nordamnacanthal and synthesized compound, Fe(II)-nordamnacanthal complex were compared. They were evaluated for the antimicrobial activity using minimum inhibitory concentration (MIC) and minimum bactericidal concentration (MBC). Fe(II)-nordamnacanthal complex showed stronger inhibition against Pseudomonas aeruginosa at the concentration of $450 \mu \mathrm{g} / \mathrm{mL}$ whereas Proteus vulgaris, Klebsiella pneumoniae and Salmonella pneumoniae at the concentration of $225 \mu \mathrm{g} / \mathrm{mL}$ compared to nordamnacanthal. In this work, the synthesized compound, Fe(II)-nordamnacanthal complex showed better antimicrobial activity compared to the ligand itself. 


\section{Nur Dzaina et al: IRON(II) COMPLEX OF ANTHRAQUINONE: SYNTHESIS, STRUCTURAL ELUCIDATION AND ANTIMICROBIAL ACTIVITY}

\section{Conclusion}

Fe(II)-nordamnacanthal complex had been synthesized successfully based on the telescoping synthesis/ one-pot reaction. The synthesized compound, Fe (II)-nordamnacanthal complex showed better antimicrobial activity compared to the ligand itself.

\section{Acknowledgment}

The study was financially supported by FRGS grant (FRGS/1/2014/ST01/UiTM/02/3). The authors would like to extend our sincere appreciation to Faculty Applied Science, UiTM Kampus 2 Samarahan, Sarawak for providing materials and chemicals needed to conduct this study successfully.

\section{References}

1. Jing J. W., Barbara J. S. and Wei Z. (2011). Cytotoxic effect of xanthones from pericarp of the tropical fruit mangosteen (Garcinia mangostana Linn.) on human melanoma cells. Food and Chemical Toxicology, 49: 2385 $-2391$.

2. Jittra K., Siriporn S., Pattiyaa L., Pranee R. and Chawanee T. (2013). Xanthone and anthraquinone-type mycotoxins from the scale insect fungus Aschersonia marginata BCC 28721. Tetrahedron Letters, 54: $3813-$ 3815.

3. Arno R. N. D., Michel F. T., Hippolyte K. W., Gerold J., Guang-Zhi Z., Peter W.r, Ning-Hua T. and Pierre T. (2014). Two new anthraquinone dimers from the stem bark of Pentas schimperi (Rubiaceae)_Phytochemistry Letters, 8: $55-58$.

4. West, B. J., Palmer, S. K., Deng, S. and Palu, A. K. (2012). Antimicrobial activity of an iridoid rich extract from" morinda citrifolia" fruit. Current Research Journal of Biological Sciences, 4(1): 52 - 54.

5. Kamiya, K., Hamabe, W., Tokuyama, S. and Satake, T. (2009). New anthraquinone glycosides from the roots of Morinda citrifolia. Fitoterapia, 80(3): $196-199$.

6. Mani G., Rangasamy L., Sethu R., Anvarbatcha R., Mohamad A. A. and Mallayan P. (2012) Interaction of mixed ligand copper(II) complexes with CT-DNA and BSA: Effect of primary ligand hydrophobicity on DNA and protein binding and cleavage and anticancer activities. Polyhedron, 52: $924-938$.

7. Li, V.S., Choi, D., Wang, Z., Jimenez, L.S., Tang, M.S., Kohn, H. (1996) Role of the C-10 Substituent in Mitomycin C-1-DNA Bonding. Journal of American Chemical Society 118: 2326-2331.

8. Zin, Z. M., Abdul-Hamid, A. and Osman, A. (2002). Antioxidative activity of extracts from Mengkudu (Morinda citrifolia L.) root, fruit and leaf. Food Chemistry, 78(2): 227 - 231.

9. Güllüce, M., Sökmen, M., Şahin, F., Sökmen, A., Adigüzel, A. and Özer, H. (2004). Biological activities of the essential oil and methanolic extract of Micromeria fruticosa (L) Druce ssp serpyllifolia (Bieb) PH Davis plants from the eastern Anatolia region of Turkey. Journal of the Science of Food and Agriculture, 84(7): 735 - 741.

10. Prista, L. N., Roque, A. S., Ferreira, M. A. and Alves, A. C. (1965). Chemical study of Morinda geminate. I. isolation of morindone, damnacanthal, nor-damnacanthal and rubiadin-1-methyl ether. Garcia de Orta, 13: 19 38.

11. Panhwar, Q. K. and Memon, S. (2014). Synthesis of Cr(III)-morin complex: characterization and antioxidant study. The Scientific World Journal, 2014: 1 - 8.

12. Ran, X. G., Wang, L. Y., Cao, D. R., Lin, Y. C. and Hao, J. (2011). Synthesis, characterization and in vitro biological activity of cobalt(II), copper(II) and zinc(II). Schiff base complexes derived from salicylaldehyde and D, Lselenomethionine. Applied Organometallic Chemistry, 25: 9 - 15. 